\title{
Offshore outsourcing of innovation by SMEs: a 4F perspective of governance
}

DOI:

10.1108/SCM-09-2020-0486

\section{Document Version}

Accepted author manuscript

Link to publication record in Manchester Research Explorer

\section{Citation for published version (APA):}

Seepana, C., Khraishi, A., Paulraj, A., \& Huq, F. A. (2021). Offshore outsourcing of innovation by SMEs: a 4F perspective of governance. Supply Chain Management: An International Journal. https://doi.org/10.1108/SCM-092020-0486

\section{Published in:}

Supply Chain Management: An International Journal

\section{Citing this paper}

Please note that where the full-text provided on Manchester Research Explorer is the Author Accepted Manuscript or Proof version this may differ from the final Published version. If citing, it is advised that you check and use the publisher's definitive version.

\section{General rights}

Copyright and moral rights for the publications made accessible in the Research Explorer are retained by the authors and/or other copyright owners and it is a condition of accessing publications that users recognise and abide by the legal requirements associated with these rights.

\section{Takedown policy}

If you believe that this document breaches copyright please refer to the University of Manchester's Takedown Procedures [http://man.ac.uk/04Y6Bo] or contact uml.scholarlycommunications@manchester.ac.uk providing relevant details, so we can investigate your claim.

\section{OPEN ACCESS}


ACCEPTED, PRE-PRINTED VERSION

For citations, please refer to the published version:

Seepana, C., Khraishi, A., Paulraj, A. and Huq, F.A. (2021), "Offshore outsourcing of innovation by SMEs: A

4F perspective of governance", Supply Chain Management: An International Journal, Vol. ahead-of-print No.

ahead-of-print. https://doi.org/10.1108/SCM-09-2020-0486

\title{
Offshore outsourcing of innovation by SMEs: A 4F perspective of Governance
}

\begin{abstract}
Purpose - In this study, we investigate how contract complexity and relational trust could impact offshore outsourcing innovation (OOI) performance of SMEs. We further examine the moderating effects of knowledge routines and joint actions on the relationships between contract complexity as well as relational trust and OOI performance.
\end{abstract}

Design/methodology/approach - Our empirical investigation extends transaction cost economics and the relational view of buyer-supplier dyads in the context of offshore outsourcing SMEs. To test our hypotheses, we collected and analysed survey data from 200 European manufacturing SMEs that have existing offshore supplier relationships.

Findings - Our results suggest that both complex contracts and relational trust as governance structures positively affect SMEs' OOI performance. Additionally, while both formal knowledge routines and joint actions help strengthen the relationship between complex contracts and OOI, they showed no significant moderating effect on the relationship between relational trust and OOI. Furthermore, based on our results, we also develop a governance framework covering four configurations - fit, firm, flexible, and fragile (4F).

Originality - The 4F governance scenarios - fit, firm, flexible, and fragile - introduced in this study emphasise the need for a combination of contract complexity and relational trust mechanisms in OOI relationships. The 4F labelling has rich implications for practitioners on how interfirm outsourcing innovation relationships can be managed based on configurations of contractual and relational governance. The study also adds to our understanding on how SMEs' specific characteristics (e.g. resource shortcomings and flexibility) may influence their OOI decisions in comparison with large firms.

Keywords Contract complexity, Governance Types, Relational trust, Offshoring, Outsourcing innovation, SMEs

Paper type Research paper 


\section{Introduction}

Firms of all sizes are increasingly engaging in outsourcing relationships as a means to attain competitive advantage (Wiengarten et al., 2013, Haleem et al., 2018, Johnsen et al., 2019). Outsourcing relationships, in general, provide firms with access to suppliers' know-how and help them tap into global markets of knowledge and talent that could potentially deliver competitive advantage (Johnsen et al., 2019, Khraishi et al., 2020). There has been a consistent positive trend towards firms' adoption of offshore outsourcing innovation (OOI) strategies in the past two decades (Lewin et al., 2009, Haleem et al., 2018). However, this positive trend has received more scholarly attention in the context of large-scale firms rather than SMEs (Gusenbauer et al., 2015). To the extent, recent studies emphasize the need to study SMEs' innovation strategies that involve offshore suppliers within the innovation process (Khraishi et al., 2020); investigating the underlying relationships between SMEs and their offshore suppliers could open up new avenues of knowledge within OOI strategies (Di Gregorio et al., 2009, Khraishi et al., 2020). Against this backdrop, our study aspires to study OOI relationships within SMEs. We view OOI to be an act of transferring any aspect of the innovation process to a foreign supplier; among others, this not only includes supplier involvement in product innovations, but also the commercialisation of such innovations (Quinn, 2000).

SMEs tend to involve in outsourcing innovation activities to offshore suppliers with the ambition of overcoming their own resource limitations (Lewin et al., 2009, Archer et al., 2008). In this sense, offshore outsourcing has been debated to be a plausible strategy to improve SMEs' innovation capabilities (van de Vrande et al., 2009). Additionally, it is also argued to enhance not only the international competitiveness of SMEs but also stimulate higher sales growth when compared to in-country outsourcing innovation activities (Rodríguez and Nieto, 2016). However, though accessing suppliers' tacit knowledge via outsourcing innovation can improve SMEs' speed of innovation, managing innovation tasks through offshore outsourcing 
will be quite challenging for SMEs (Haleem et al., 2018). Mainly, such activities could lead to risks associated with knowledge spillovers which may result in a loss of competitive advantage (Aubert et al., 2015, Hoecht and Trott, 2006). To address such concerns, employing appropriate governance mechanisms to oversee OOI relationships is likely to be of paramount importance to SMEs given that: (1) outsourced innovations are unpredictable and uncertain (Stanko and Calantone, 2011); (2) offshore suppliers pose higher behavioural risks (Huq et al., 2014, Ciliberti et al., 2009); and (3) offshore countries have different business and institutional environments (Huq and Stevenson, 2020).

Accordingly, firms that pursue innovation through outsourcing are encouraged to formulate effective interfirm governance mechanisms to not only mitigate outsourcing innovation risks, but also to improve potential innovation outcomes (Sumo et al., 2016, van der Valk et al., 2016). These governance mechanisms could be of different types. For example, Pittino and Mazzurana (2013) suggest that firms tend to rely on relational governance in innovation exploitation alliances, however, they use a combination of both contractual and relational governance in case of exploration innovation alliances. Similarly, Sumo et al. (2016) and Melander et al. (2014) indicate the need for both contract and trust based governance to achieve medium or high levels of innovation in interfirm relationships. Accordingly, extant literature suggests the significance of employing both contractual and trust-based governance mechanisms in relational settings that aim to develop innovations. However, it is unclear whether such governance mechanisms could offer sufficient support for innovation generation for SMEs involved in OOI relationships. Therefore, our study extends this line of research by explicitly investigating how SMEs implement different types of contractual and relational governance to enhance the innovation performance of offshore outsourcing relationships. We conceptualise OOI performance as the product and process innovations, and the new product speed to market resulting from the SME-offshore supplier dyadic exchange (Jean et al., 2012). 
In addition to the prominence attached to contractual and relational governance mechanisms to advance performance outcomes such as innovations, firms in dyadic relationships also increasingly pursue relational routines such as formalizing and integrating knowledge flows (Haleem et al., 2018, Stratman, 2008), engaging in collaborative works (Lavikka et al., 2015) such as joint actions and joint decisions, and transaction-specific investments (Handley and Benton, 2013). The rationale for pursuing such relational routines is attributed to their ability to facilitate contractual as well as relational mechanisms (Haleem et al., 2018) to better manage offshore relationships (Stratman, 2008) and, ultimately, improve performance outcomes (Haleem et al., 2018). Therefore, it is plausible to argue that such alliance bonding activities can complement contracts as well as trust-enabling governance mechanisms so as to improve partners' performance. However, the complementary effects of such relational routines on governance mechanisms and subsequent performance outcomes is quite unclear, particularly, among offshoring firms (Youngdahl et al., 2008, Haleem et al., 2018). Accordingly, we also investigate the moderating effects of relational routines (in our case, knowledge routines and joint actions) on the relationship between governance mechanisms and OOI performance. OOI performance reflects firms' ability to (1) develop new as well as improved products and processes, (2) take new products to the markets faster, and (3) increase number of patent applications as a result of relationships with offshore suppliers (Rindfleisch and Moorman, 2001, Jean et al., 2012).

Our study intends to make significant contributions to extant research on OOI by testing the relationships showcased in the conceptual model (Figure 1). First, our study contributes to the literature of OOI in SMEs by revealing alternative governance types of OOI relationships, since SMEs simply cannot be viewed as miniature versions of larger firms (Gusenbauer et al., 2015). Specifically, the $4 \mathrm{~F}$ governance scenarios fit, firm, flexible, and fragile introduced in this study adds to extant literature (Cao and Lumineau, 2015, Devos et al., 2012, Liu et al., 
2009) that discusses the need to attain a better understanding of the different combinations of contractual and relational trust mechanisms. These findings also add to the calls that seek to (1) build specialized knowledge which combines contractual and trust-based mechanisms within the context of SMEs (Ciliberti et al., 2009, Mirkovski et al., 2016), and (2) identify critical combinations of key factors that could facilitate innovation (Zimmermann et al., 2016). Second, our results highlight the significance of adopting both contractual complexity and relational trust governance mechanisms by SMEs so as to enable outsourcing innovation strategies with their suppliers. This result further contributes towards the debate (Cao and Lumineau, 2015, Haleem et al., 2018) that highlights insufficient and inconclusive knowledge with regards to the use of dual governance structures and their performance effects for offshoring SMEs. Third, the moderation effects add to the current understanding on the importance of relational norms (Mirkovski et al., 2016) - our results showcase varying effects of the relational norms in facilitating dual governance mechanisms for managing innovation activities within offshoring SMEs - while both knowledge sharing routines and joint actions are found to strengthen the relationship between contract complexity and OOI performance, they do not have a significant moderating effect on the relationship between relational trust and OOI performance.

[Insert Figure 1 about here]

\section{Theory and Hypotheses}

\section{The nature of outsourcing innovation}

Outsourcing is typically driven by cost, efficiency and economies of scale considerations (Gooroochurn and Hanley, 2007). When it comes to outsourcing innovation in particular, it is a coupled process wherein its success requires higher levels of cooperation between outsourcing partners than in the case of outsourcing low-value activities (e.g. production, where disintegration is rather prominent) (Palmié et al., 2015). In outsourcing innovation, firms face a fundamental paradoxical tension between outsourcing efficiency (e.g. low uncertainty, 
Governance of offshore outsourcing innovation by SMEs

process standardisation, and measurability), and innovation adaptability (e.g. risk taking, flexibility, and slack resources) (Aubert et al., 2015). Through outsourcing efficiency, firms monitor and control suppliers to achieve low transaction costs and economic gains. Alternatively, innovation adaptability entails having sufficient resources, decentralised governance structure and open knowledge sharing (Aubert et al., 2015). Consequently, firms pursuing innovation through outsourcing must manage this paradox by establishing governance mechanisms that satisfy a dual need for outsourcing success and innovation capacity (Kulangara et al., 2016).

\section{Transaction cost economics and relational view as underpinning theoretical anchors}

Firms that pursue innovation through outsourcing are generally confronted with two contrasting approaches. The first approach is in favour of limiting suppliers' involvement in the innovation process to non-core and low-cost innovation activities. The second approach, however, values suppliers' early involvement in the innovation process due to suppliers' specific and strategic competencies as in the case of specialised first-tier suppliers in the automotive industries (Dyer, 1996). The first approach is a common practice during the transformation of innovation knowledge into real innovation (e.g. outsourcing design and prototyping services) (Roper et al., 2008). This approach is consistent with transaction cost economics (TCE). It explains innovation generation in buyer-supplier relationships as a function of adaptation costs (e.g. contract adjustments), safeguarding costs (e.g. curbing supplier opportunistic behaviour) and measurement costs (e.g. monitor contract implementation) (Stanko and Calantone, 2011). Accordingly, firms will favour a "buy" instead of a "make" strategy for as long as they can justify and afford transaction cost implications (Lai et al., 2009). With the second outsourcing innovation approach which structurally and systematically integrates the suppliers in the buyers' innovation process, it involves prohibitive transaction costs. Therefore, this approach constitutes a breakdown of TCE's traditions (Stanko and Calantone, 2011). Hence, the motivation for firms to adopt this approach is likely driven 
by survival or profitability instincts rather than the notion of transaction cost economics (Gooroochurn and Hanley, 2007). Specifically, the relational view theory (RVT) supports this alternative conceptualisation for OOI. In OOI, the buyer firm gains access to suppliers' specialised resources and tacit knowledge which are neither easier to develop in-house nor readily available to buy utilising arm's length ties (Dyer and Singh, 1998). Dyer (1996) emphasizes that firms continually use collaboration to expand their competencies and relational rents. To this extent, the concept of relational rent has been utilised to explain how firms of various sizes chose their outsourcing partners to set up preferred types of relationships (McIvor, 2005). The overarching message of relational view theory is that a firm's ability to attain competitive advantage lies not only in its own resources but also from idiosyncratic resources that firms could acquire through collaborative arrangements (Dyer and Singh, 1998, Dyer et al., 2018).

\section{Juxtaposing TCE and RVT}

RVT (Dyer and Singh, 1998, Dyer et al., 2018), as an extension of resource-based view, is argued to have developed from the limitations of TCE (Williamson, 1991) in explaining various interfirm governance structures (McIvor, 2009, Marshall et al., 2007). A growing body of literature argues that the views offered by these theories can be complementary and that either one of these theories, on their own, cannot fully explain firms' choices in certain cases (Vivek et al., 2008, Madhok, 2002, Marshall et al., 2007). The complementary nature of these theories is attributed to the premise that specific assets and capabilities of firms that are involved in interfirm relationships are difficult to either trade or imitate (Peteraf, 1993, McIvor, 2009). Such characteristics necessitate the need to bring together the tenets of both these theoretical perspectives. For instance, TCE focuses primarily on establishing efficient governance to anchor interactions between partners (McIvor, 2009, Williamson, 1991, Marshall et al., 2007), whereas RVT provides a useful lens to study how processes involved in 
interfirm relationships can be improved by leveraging resources and capabilities, and appropriate governance structures to attain superior performance outcomes such as innovation (Chou et al., 2015, Dyer et al., 2018).

In addition to its ability to explain the potential linkages between governance and competitiveness, TCE also adds that firms are 'boundedly rational', and, therefore, struggle to predict possible contingencies for their transactions (Mukherjee et al., 2019) despite the use of governance mechanisms to oversee their transactions. Therefore, the proponents of TCE contend that a potential channel to address such contingencies and subsequently improve trust and overall gains is by complementing the underlying governance with appropriate relational norms or routines (Mudambi and Tallman, 2010). Accordingly, the tenets of TCE point towards the significance of employing relational norms as discussed by the RVT scholars (Dyer and Singh, 1998, Dyer et al., 2018) to not only complement transactions between partners (Schmoltzi and Wallenburg, 2012), but also to develop trust (Hernández-Espallardo et al., 2010). The RVT adds that governance structures used in dyadic relationships will help create relational rents (Dyer and Singh, 1998, Dyer et al., 2018); the strength of such relational rents could get further compounded when partners employ relational routines such as knowledge exchanges that can complement the underlying governance structures to develop trust as well as to realize higher relational rents (Hernández-Espallardo et al., 2010, Helen et al., 2013). However, studies emphasise that these outcomes of trust and relational rents as a result of RVT elements require the support of TCE structures such as contracts to reduce opportunistic behaviour (Liu et al., 2009). Nonetheless, TCE consistently argues for the need for managers to consider alternative governance by which firms can exploit their resources (Williamson, 1991); to which the RVT and resource based view tenets acknowledge that such resources can be better exploited in buyer-supplier relationships with the use of appropriate routines to complement the governance structures (Silverman, 1999). Accordingly, the tenets of both TCE 
and RVT suggest that there is an underlying complementarity between both the theoretical anchors and that it is important to juxtapose both to address not only the governance structures, but also other complementary variables such as knowledge routines and joint actions.

Our study understands this need to juxtapose both TCE and the RVT as their combination can offer a more realistic picture to explain various forms of governance for interfirm OOI relationships. The need to address various governance structures is pertained to the argument that (1) trust is essential between trading partners to attain competitive advantage and to reduce transaction costs, and (2) employing formal or informal forms of governance alone may not be sufficient (Devos et al., 2012, Chen et al., 2013). Given that neither TCE nor RVT alone can explain effective forms of governance (Ribbink and Grimm, 2014), the complementarity between TCE and RVT is likely to better explain arguments specific to both trust and contract-based governance forms (Chen et al., 2013) as well as their combinations.

\section{Contract complexity}

Contracts are unavoidably complex in case of OOI given the higher degrees of asset specificity, behavioural uncertainty, performance ambiguity and risks of outcome (Poppo and Zenger, 2002, Bidault and Castello, 2010). In this research, we define contract complexity as the formal buyer-supplier contract which details parties" "roles and responsibilities, specifies procedures for monitoring and penalties for noncompliance, and, most importantly, determine outcomes or outputs to be delivered" (Poppo and Zenger, 2002, p708). Previous studies suggest that complex contracts that monitor outsourcing relationships for new product development can enhance the performance of these relationships. For example, contracts are useful instruments to measure the performance output of the offshore supplier (Stanko and Calantone, 2011, Glas and Eßig, 2018, Prajogo et al., 2020). Moreover, contracts can enhance outsourcing innovation performance by setting ex-ante objectives, which, in turn, help to keep suppliers motivated and focused on meeting the OOI goals (Carson, 2007). Also, complex contracts of strategic 
outsourcing act as an insurance policy since they serve as legal safeguards against wrongdoing (Hoecht and Trott, 2006, Wiengarten et al., 2013). Scholars argue that complex contracts not only safeguard against ex-post performance issues but are also excellent facilitators of knowledge transfer and can improve innovation outcomes in buyer-supplier relationships (van der Valk et al., 2016, Swierczek, 2019). Besides, SMEs could employ formal contracts in exploration innovation alliances as an essential control mechanism to compensate for their small scale vulnerability in foreign markets and dependencies on external suppliers (Pittino and Mazzurana, 2013). Therefore,

H1: Contract complexity in OOI relationships positively affects OOI performance in SMEs.

\section{Relational trust}

In this research, we define relational trust as the trusting party's (i.e. the SME outsourcing firm) faith that the other party (i.e. the offshore supplier) in the OOI relationship will act in favour of the outsourcing firm's welfare (Ring and van de Ven, 1994). To that extent, relational trust is a measure of benevolence or the non-calculative component of trust (Mayer et al., 1995). It reflects the level of an SME's confidence that its offshore supplier will choose collective-gains over self-gains when the possibility for opportunistic behaviour is present (Gulati and Sytch, 2008, Archer et al., 2008). The relational trust provides an effective means to manage the interdependence between the two firms, allowing effective pooling of complementary tacit knowledge resources under reduced fears from opportunism (Dyer and Singh, 1998, Bordonaba-Juste and Cambra-Fierro, 2009, Swierczek, 2019). The relational trust also explains firms' behaviour in making business decisions that impact their interfirm relationship outcomes beyond their contractual obligations (Saparito et al., 2004, Swierczek, 2019, Melander et al., 2014). For example, Bidault and Castello (2010) proposed that the interpersonal nature of relational trust highlights the role played by executives involved in managing interfirm 
innovation projects in how they adapt their decision-making process to accommodate various contingencies and risks of OOI activities.

SMEs benefit more than large firms from relational trust-based interfirm relationships given the dominant role of SMEs' entrepreneurs in managing these relationships (Kulangara et al., 2016, Mirkovski et al., 2016). For example, Pittino and Mazzurana (2013) and Kühne et al. (2013) indicate that trust, among other relational governance norms, is increasingly adopted by SMEs to control and coordinate innovation alliances, primarily due to their resource disadvantage in crafting and monitoring complex contracts. Also, relational trust enhances team spirit across buyer-supplier dyads, acts as a filter for information sharing, and reduces the effect of innovation ambiguities and risks (Kulangara et al., 2016, Zimmermann et al., 2016). Summing up, relational trust also stands a strong chance to improve OOI performance for SMEs. Thus, we propose the following hypothesis:

H2: Relational trust in OOI relationships positively affects OOI performance in SMEs.

\section{The interaction between Contract Complexity and Relational Trust}

Interfirm research has concluded that in managing buyer-supplier cooperative relationships firms cannot in practice rely exclusively on either contract complexity or relational trust (Poppo and Zenger, 2002, Ring and van de Ven, 1994, Johnsen et al., 2019). Also, the added complexity of managing OOI relationships related to both behavioural and outcome risks seems to call for a purposeful combination of contract complexity and relational trust (Carson, 2007). It is well known that innovation requires tacit knowledge disclosure and highly specific investments with significant hold-up risks (Gooroochurn and Hanley, 2007). Therefore, there is a greater need for contract complexity to motivate tacit knowledge exchange and innovation investment decisions (Mirkovski et al., 2016, Gooroochurn and Hanley, 2007, Glas and Eßig, 2018). At the same time since innovation is expensive, risky, and uncertain, increased levels 
Governance of offshore outsourcing innovation by SMEs

of relational trust emerge as a necessary condition to promote non-calculative investment behaviour (Kulangara et al., 2016, Swierczek, 2019).

Contract complexity employs legal means in the specification of contingencies, adaptation, and mitigation of opportunistic behaviour (Dyer and Singh, 1998). On the other hand, relational trust utilises personality traits to guarantee the intent of mutuality, bilateralism, and continuation in the face of unforeseen contingencies (Zaheer et al., 1998). In summary, combining both mechanisms not only compensates for contract incompleteness and avoids the dark side of relational trust (i.e. distrust), but also captures both mechanisms' synergetic value through reduced control and coordination costs and improved OOI performance (Poppo and Zenger, 2002). The proponents of both TCE and RVT reckon that the complementarity between these theoretical perspectives could provide a powerful grounding to explain governance mechanisms in buyer-supplier relationships (Ribbink and Grimm, 2014, Liu et al., 2009); however, when viewed individually, they provide insufficient justifications to sufficiently explain buyer-supplier relationships (Ribbink and Grimm, 2014). Accordingly, this study subscribes to the juxtaposing of both TCE and RVT that supports the complementarity relationship between contract complexity and relational trust. Thus, we advance:

H3: Contract complexity and relational trust act as complements in SMEs OOI relationships.

\section{The moderating role of formal knowledge routines}

The study views formal knowledge routines as the structured processes that regulate and coordinate knowledge sharing between the outsourcing SME and the offshore supplier (Roy and Sivakumar, 2011). Formal knowledge routines can include written rules and procedures for accessing, exploiting, and protecting tacit knowledge in OOI relationships (Noordhoff et al., 2018, Roy and Sivakumar, 2011). It also includes formalised learning and communication interactions such as joint project teams, formal visits and the use of shared information technology (IT) platform for knowledge sharing (Kwon and Suh, 2004). 
For OOI, accessing an offshore supplier's tacit knowledge and pooling them with the outsourcing SME's tacit knowledge is a central premise (Hoecht and Trott, 2006). OOI grants SMEs access to resources and skills that are not only integral to offshore suppliers, but also essential for their survival and growth (Rodríguez and Nieto, 2016). However, the trade-off between accessing the offshore suppliers' tacit knowledge and the risk of the buyers' tacit knowledge leakage is often a source of tension between governance efficiency and innovation performance in OOI relationships (Aubert et al., 2015, Lai et al., 2009). For example, Roy and Sivakumar (2011) proposed that firms pursuing innovation through offshore outsourcing need to be aware of the implications of their formal OOI contracts on intellectual property (IP) management. On the one hand, complex contracts in OOI can discourage suppliers from sharing their tacit knowledge and hence derail the OOI performance (Hoecht and Trott, 2006). On the other hand, a contractual allocation of IP rights to suppliers who contributed the most to an innovation generation has a strong positive influence on the collaboration output (Kloyer and Scholderer, 2012). Consequently, formal knowledge routines can act as a formal cooperative catalyst of contract complexity through signalling both the buyer and the supplier top managements' commitment to collaborate, thereby refining knowledge sharing and eventually leading to higher OOI performance (Bidault and Castello, 2010).

Similarly, consistent with the tenets of TCE and relational view, extant literature reckons that interfirm relationships are characterised by high levels of tacit knowledge exchanges that could enable trust between partners (Levin and Cross, 2004, Kembro et al., 2014, Zimmermann et al., 2016). Therefore, formal knowledge routines can quantify the value of parties' trustworthy behaviour through structural tacit knowledge exchanges which institutionalises transparency and alleviates perceived risks of tacit knowledge misappropriation or "free riding" behaviour (Mayer et al., 1995). To this extent, formal knowledge routines are especially important for SMEs, more than large firms, since SMEs lack 
the management resources to build strong ties and a substantial stock of relational trust (Lewin et al., 2009, Archer et al., 2008). Typically, SMEs tend to trust suppliers due to insufficient time and resources to assess suppliers' trustworthiness (Pittino and Mazzurana, 2013). Moreover, managing the cross-border relationship is difficult for SMEs due to the physical, institutional, and cultural distances with the foreign markets (Jean et al., 2012, Pawar et al., 2020). Consequently, formal knowledge routines are likely to stimulate the role of relational trust in SMEs' OOI relationships by levelling the tacit knowledge sharing and protection playfield with offshore suppliers. Besides, ensuring a continuous and sustainable two-way flow of information and ideas is essential to OOI success (van den Ende et al., 2015). Accordingly, H4a: Formal knowledge routines positively moderate the effect of contract complexity on OOI performance in SME.

H4b: Formal knowledge routines positively moderate the effect of relational trust on OOI performance in SME.

\section{The moderating role of supplier joint actions}

As a relational norm, joint actions act as strong incentives for buyers and suppliers to exercise control and coordination (Khraishi et al., 2020). Specifically, supplier joint actions are likely to add higher value to the alignment and effectiveness of governance mechanisms in OOI relationships (Kim et al., 2015). Offshore suppliers perceive such actions as strong indications of the buyer SMEs' willingness to "give and take" and their consideration of the suppliers' interests (Khraishi et al., 2020).

The proponents of TCE recommend additional relational norms such as joint actions could serve as useful routines to complement partners' transactions (Schmoltzi and Wallenburg, 2012); RVT expresses similar views by exhibiting that relational norms such as joint activities could supplement established governance mechanisms between partners to not only develop trust, but also to help improving relationship performance (Helen et al., 2013). Extant literature posits that rewarding suppliers for improved performance will likely have a 
conducive effect on the suppliers' efforts and behaviour towards the buyers' interests (Shepherd and DeTienne, 2005). In OOI, such rewards can include the SME-supplier joint activities aimed at supplier development such as working in conjunction with the supplier to improve its cost efficiencies and quality (Khraishi et al., 2020). Specifically, SMEs' focused efforts to improve the offshore supplier profit and performance in the OOI relationship can be more effective given the difficulty of performance measurement and the uncertainty of OOI outcomes (Felin and Zenger, 2014). Therefore, joint actions with suppliers can ensure that they take appropriate efforts to fulfil complex contracts and contribute significantly to OOI performance (Liu et al., 2010). However, the lack of such joint actions could rather lead the suppliers to fear the SMEs' illegal behaviours; this can consequently lead to contractual noncompliance and inferior OOI performance (Mooi and Ghosh, 2010).

Additionally, given such joint actions focus more on securing economic gains for the offshore supplier, they can also significantly moderate the effect of socialization on performance (Kim et al., 2015, Mirkovski et al., 2016). For instance, frequent interaction, training programs, and technical meeting with the offshore supplier's innovation teams will encourage the supplier to make desirable contributions to OOI and can further enhance the effect of relational trust on innovation (Kulangara et al., 2016). Also, following the rationale of trust research, intense and formalised social interactions through supplier joint actions increase the offshore supplier willingness to contribute to OOI success even before building relational trust through long exchange history (Levin and Cross, 2004). Moreover, through supplier joint actions, SMEs claim an attractive partnering stance which signifies the effect of the offshore suppliers' perceptions about the SME's trustworthiness and boost the degree of the offshore suppliers' commitment towards achieving OOI success (Koufteros et al., 2012). Therefore, we forward the following hypotheses for formal testing: 
Governance of offshore outsourcing innovation by SMEs

H5a: Supplier joint actions positively moderate the effect of contract complexity on OOI performance in SME.

H5b: Supplier joint actions positively moderate the effect of relational trust on OOI performance in SME

\section{Methodology}

The study of offshore outsourcing relationships could offer opportunities to discover excellent insights for both research and practice, particularly the exploration of OOI (Rodríguez and Nieto, 2016, Haleem et al., 2018). We chose the specific context of buyer-supplier due to the fact that SMEs, given their resource limitations, tend to prefer non-equity relationships over captive relationships (Rodríguez and Nieto, 2016). Non-equity based outsourcing relationships are better than equity-style arrangements (Khraishi et al., 2020) as they can (1) better assist in the sharing of risks associated with innovations, and (2) allow to rapidly move into different markets as well as technologies (Quinn, 2000). We have employed a cross-sectional survey to collect data; this approach is in line with previous studies that share similar population and context (van de Vrande et al., 2009). The unit of our analysis is the SME-offshore supplier dyad.

\section{Sampling and data collection}

We collected data from manufacturing SMEs in the United Kingdom as well other developed European countries such as France, Germany, and Italy. According to the European commission, European SMEs remain the backbone of European economy as they make up $99.8 \%$ of all enterprises (barring financial sector) in Europe and also contribute to the creation of two-thirds of employment (European-Commission, 2019). Specifically, manufacturing sector SMEs account for $58 \%$ of employment and $42 \%$ of value addition to the European economy (European-Commission, 2017). These SMEs contribute immensely to the European manufacturing sector with a revenue generation of over $€ 725$ billion which is equivalent to 
$44.5 \%$ of the manufacturing sector's value in 2013 (Eurostat, 2016). Besides, when it comes to innovation performance in Europe, over $49.1 \%$ of all European firms have acknowledged their involvement in different forms of innovation activities between 2012 and 2014 (Eurostat, 2017). A similar percentage was found among the SMEs as well. Given their significance, European SMEs are receiving increased recognition from the EU policy makers for their involvement in $\mathrm{R} \& \mathrm{D}$ activities and their contribution to the European innovation ecosystem (De Marco et al., 2020). To support SMEs, the EU has launched SME Instrument (SMEi) project to enable the SMEs to pursue high-risk as well as ambitious projects to develop innovation (EASME, 2018). Accordingly, in light of the importance awarded to European SMEs, we have specifically chosen European SMEs as the context for the study.

We employed 'Qualtrics' panel services to access the database of offshoring firms within Europe. Recent years have noticed a significant interest in the use of such panel services in general management (Seepana et al., 2020, Statsenko and Corral de Zubielqui, 2020) as well as operations management (Abbey and Meloy, 2017, Seepana et al., 2021). We have identified an initial sampling frame of 2,384 firms with the assistance of 'Qualtrics' services that match our criteria of firms that involve in offshore relationships. These firms are located in UK, Germany, Italy, and France; however, the selected offshore supplier is located outside the location wherein each firm currently operates. This criterion matches the offshore firm selection norms as established in extant research (Khraishi et al., 2020, Geishecker and Görg, 2013). In effect, these selection criteria fit into our study's context of a dyadic relationship between an SME and its offshore supplier. We eliminated 1,359 firms from our initial sample of 2,384 firms as they did not fit the EU definition of SMEs - EU classifies SMEs to have an employee size between 10 - 249 and to have a turnover of less than $€ 50$ million (EuropeanCommission, 2016). We specifically chose to seek responses from non-captive offshore innovation arrangements rather than captive arrangements; this decision is attributed to the 
debate that suggests non-equity relationships to be more attractive for SMEs (Rodríguez and Nieto, 2016). Additionally, equity relationships require high-levels of alliance-specific investments compared to non-equity based relationships; non-equity based relationships are also less expensive and less complex when a partner decides to exit from such relationships (Globerman and Nielsen, 2007). Accordingly, we have further screened out firms that were involved in captive/equity-based arrangements. These initial screening of responses led to a reduced sample frame of 918 SMEs that pursue non-captive OI relationships with their suppliers. We requested the respondents to choose an offshore supplier with whom they have an ongoing OOI relationship when answering the online survey.

We targeted key executives within these SMEs - surveying top-level executives from buying firm, in our case SMEs, is a common practice in management research (Paulraj et al., 2008). Our decision to target top executives is grounded in extant literature that suggests that executives of SMEs tend to take responsibilities to manage their strategic relationships with their suppliers (Bidault and Castello, 2010, Gusenbauer et al., 2015). Accordingly, we ensured our respondents were mainly CEOs and managing directors. We received 223 responses; 23 of these response were eliminated due to (1) a high proportion of missing answers, and (2) the responses having been completed in less than a third of the median time taken for others to complete the survey (Brazhkin, 2020). Although we have included attention check questions to minimize low-quality responses, we have not found any low-quality responses for further elimination. As a result, our final sample consists of 200 valid responses with an effective response rate of $21.78 \%$. The final sample characteristics are presented in Table 1 .

[Insert Table 1 about here]

\section{Measures}

The survey instrument consisted of multi-item variables that were operationalized based on extant research. The survey indicators utilized a 7-point Likert scale with endpoints "strongly 
disagree" to "strongly agree". Prior to data collection, we pre-tested the instrument by seeking responses to our survey from eight manufacturing executives. These executives also provided feedback on survey language, structure, and the coverage of the examined constructs. The final survey incorporated some changes based on the feedback we received from the expert practitioners.

"Contract complexity" was operationalised by four items (1) two items from Poppo and Zenger (2002) measuring the extent of contract length and customisation, and (2) two items from Ferguson et al. (2005) measuring the number of rules and regulations included in the contract and the contract's degree of adaptability. We operationalised "relational trust" through four items measuring the outsourcing SME perceptions on whether the offshore supplier keeps its promises, is sincere, is concerned about the outsourcing SME's welfare (Kwon and Suh, 2004), and has been even-handed in its negotiations with the outsourcing SME (Zaheer et al., 1998). We measured "formal knowledge routines" with four items examining the extent to which the outsourcing SME relies extensively on contractual knowledge exchange rules, follows written procedures in most aspects of knowledge sharing (Noordhoff et al., 2011), establishes ground rules about knowledge exchange, and uses a common information technology (IT) software to control knowledge sharing (Kwon and Suh, 2004). We operationalised "supplier joint actions" using a three-item scale that captured how extensively the outsourcing SME worked with the offshore supplier to improve cost and quality performance as well as to train the supplier's employees (Joshi and Stump, 1999). Finally, a four-item scale was utilized to measure OOI performance; among others, this scale focused on speed to market as well as rate of patent applications (Rindfleisch and Moorman, 2001, Jean et al., 2012).

\section{Control variables}


OOI relationships are cooperative in nature, and hence they can evolve and grow from transactional (short term) to collaborative (long term) relationships through accumulation of relational trust and reduction of fears from opportunism (Vivek et al., 2009). Therefore, we identified relationship longevity and respondent's length of experience (manager tenure) with the SME outsourcing firm as our first two control variables. We measured longevity and manager tenure as the natural logarithm (Lincoln and Guba, 1985) of years of dyadic relationship and manager's years of experience respectively (Gulati and Sytch, 2008). Also, we controlled for three categorical variables of firm size (small or medium), SMEs' country, and industry technology intensity following OECD technology intensity and industry classifications (OECD, 2011).

\section{Common method bias}

This study collected data from a single respondent within each of the surveyed SMEs; therefore, we conducted specific tests to assess the presence of common method bias. A confirmatory factor analysis was used for this purpose. Specifically, we ran two models - one with a single-method-factor while the other included all the constructs employed in the study. The model fit for the single-method-factor model (Comparative fit index $[\mathrm{CFI}]=0.762$, Tucker-Lewis index $[\mathrm{TLI}]=0.722$, Root mean square error of approximation $[$ RMSEA $]=$ 0.124) was considerably worse in comparison to our proposed model $(\mathrm{CFI}=0.949$, $\mathrm{TLI}=$ 0.933, RMSEA $=0.061$ ). This result signifies that common method bias might not be of concern (Sanchez and Brock, 1996). Additionally, recent studies argue that although single respondent surveys tend to be susceptible to biases, they are not problematic when it comes to SMEs as the narrow management bandwidth of SMEs can help single-key respondent research to adequately capture the strategic activities of such firms (Kull et al., 2018).

\section{Instrument development}

We conducted CFA utilizing AMOS 20.0 to establish the reliability, validity, and unidimensionality of our measurement items. The model fit for the data is found to be 
Governance of offshore outsourcing innovation by SMEs

satisfactory - the CFA fit indices include; normed $\chi^{2}[\mathrm{NC}]=1.75, \mathrm{p}<0.001$, Goodness of Fit $(\mathrm{GFI})=0.914$, Adjusted Goodness of Fit $(\mathrm{AGFI})=0.870, \mathrm{CFI}=0.949, \mathrm{TLI}=0.933, \mathrm{RMSEA}$ $=0.061$, Standardized Root Mean Square Residuals $(\mathrm{SRMR})=0.053$. We established discriminant validity using the Fornell and Larcker (1981) criteria. As per this test, the AVE values of any two constructs in a given model should be higher than the squared correlation between them. Our results suggest that the correlation coefficients of all pairs of constructs are lower than the AVE values of the respective constructs. Additionally, the highest squared correlation of 0.38 (correlation $=0.615)$ between relational trust and supplier joint actions is lower than their AVE values (i.e., 0.53 and 0.52, respectively). These results sufficiently establish that the measurement items have discriminant validity. To establish the reliability of our indicators, we used the measure of composite reliability; the composite reliability for all constructs were found to be higher than 0.70. Also, given that Cronbach's alpha for all constructs $\geq 0.7$, the reliability of the measurement items is re-confirmed. Additionally, computed AVE for all constructs, as shown in the Appendix, is $\geq 0.50$. Taken together, we can conclude that the constructs of the study exhibit acceptable convergent validity (Fornell and Larcker, 1981).

\section{Results}

\section{Hypotheses testing}

We tested our hypotheses using multiple ordinary least square (OLS) regression models. Table

2 contains the results pertaining to hypotheses $\mathrm{H} 1$ through $\mathrm{H} 5 \mathrm{~b}$. Hypothesis $\mathrm{H} 1$ predicts contract complexity to positively affect OOI performance. The results indicate that contract complexity's effect on OOI performance (Model 1) $($ Beta $=0.168, p<0.05)$ is positive and significant, thereby supporting hypothesis H1. Similarly, hypothesis H2 predicts that relational trust will positively affect OOI performance; results show that the effect between relational 
trust and OOI performance (Model 1) $($ Beta $=0.295, \mathrm{p}<0.01)$ is positive and significant, thereby supporting hypothesis $\mathrm{H} 2$.

As for the moderation effects, hypotheses $\mathrm{H} 4 \mathrm{a}$ and $\mathrm{H} 4 \mathrm{~b}$ predict that formal knowledge routines will positively moderate the relationships between contract complexity and OOI performance as well as relational trust and OOI performance. The results suggest that the introduction of formal knowledge routines causes a stronger positive effect between contract complexity and OOI (Model 3) $($ Beta $=0.299, \mathrm{P}<0.01)$, thus, offering support to hypothesis H4a. However, the moderating effect of knowledge routines on the relationship between relational trust and OOI performance is negative and insignificant, thereby not supporting hypothesis $\mathrm{H} 4 \mathrm{~b}$. When it comes to hypothesis $\mathrm{H} 5 \mathrm{a}$ and $\mathrm{H} 5 \mathrm{~b}$, supplier joint actions is hypothesized to positively moderate the effects between contract complexity and OOI performance as well as relational trust and OOI performance. The implementation of the supplier joint actions appears to strengthen the effect of contract complexity on OOI performance $($ Model 4) $($ Beta $=0.189, \mathrm{P}<0.01)$, thus, supporting hypothesis H5a. However, the moderating effect of supplier joint actions on the relationship between relational trust and OOI performance is negative and insignificant, thereby not providing support to hypothesis H5b. Finally, in model 5, we include all latent variables and moderators in the regression model. The results of model 5 confirm the moderating effect of formal knowledge on the relationship between contract complexity and OOI performance.

[Insert Table 2 about here]

\section{The relationship between contract complexity and relational trust}

To test for the hypothesis $\mathrm{H} 3$ that posits a potential complementarity between contract complexity and relational trust, we used two different tests. The first test shown in Table 2 (model 2) introduces an interaction term (contract complexity x relational trust) in an OLS regression analysis. The test evaluates not only the effect of the interaction term on OOI 
performance, but also observes the marginal increase in the direct effects of contract complexity and relational trust on OOI performance. As shown in Table 2 the interaction effect of contract complexity and relational trust is significant (model 2$)($ Beta $=0.186, p<0.05)$. Also, it has a positive and significant effect on the strength of the effect of contract complexity (Beta $=0.234, \mathrm{p}<0.01)$ and relational trust $($ Beta $=0.378, \mathrm{p}<0.001)$ on OOI performance, and hence, supports the hypothesis $\mathrm{H} 3$.

The second test follows a productivity approach in determining the effect of complementary practices on productivity performance. For example, Cassiman and Veugelers (2006) follow the same model to analyse complementarity among innovation activities, focusing on internal R\&D (make) and external knowledge acquisition (buy). To conduct this test, we first divided our sample into four sub-groups of governance types a) high contract complexity / high relational trust (96 SMEs, 48\%), b) high contract complexity / low relational trust (26 SMEs, 13\%), c) low contract complexity / high relational trust (37 SMEs, 18.5\%), and d) low contract complexity / low relational trust (41 SMEs, 20.5\%).

Moreover, to establish the four sub-groups, we created a dummy variable for each subgroup with value 1 for firms within the sample that rely strongly on contract complexity/relational trust and 0 for firms that depend less on contract complexity/relational trust. First, we gave 1 for values above the mean and 0 to equal or less than the mean. Second, we tested for the effect of contract complexity and relational trust complementarity in the measure of OOI performance by running an equality test of means between sub-groups and within groups (Cassiman and Veugelers, 2006, Pittino and Mazzurana, 2013). The one-way ANOVA resulted in significant $F$ statistics $(3,196)=15.890, \mathrm{P}<0.001)$, suggesting that the complementarity condition between contract complexity and relational trust is met.

In Figure 2, we map our results of the four groups of different governance types (Table 2 - Model 4) using MATLAB (Mathworks-R2018a) with OOI outcomes. We plotted OOI 
results with the means of contract complexity and relational trust. The $\mathrm{x}$-axis is used to plot the mean of contract complexity and the y-axis is utilised to plot the mean of relational trust and the distribution of OOI results. As shown in Figure 2, a total of $84.4 \%$ of the SMEs' managers who implemented high contract complexity and high relational trust reported high OOI performance (above the mean of OOI in all results). Moreover, 78\% of the SMEs in our study who exhibited a general propensity towards adopting a governance type with low contract complexity and low relational trust reported low OOI performance (below the mean of OOI in all results).

[Insert Figure 2 about here]

\section{Discussion}

\section{Governance types in SMEs offshore outsourcing innovation relationships}

Our results indicate that the majority of the SMEs employ complex contracts and rely on relational trust to enhance OOI performance. Although this result is broadly consistent with Poppo and Zenger (2002), it is less compatible with recent SME studies. For example, Pittino and Mazzurana (2013) and Kühne et al. (2013) suggest that SMEs are more inclined to rely only on relational governance/trust in exploitation innovation alliances. Also, SMEs tend to use a combination of both contract and trust in case of pursuing medium-high innovation levels in buyer-supplier relationships (van der Valk et al., 2016). However, the majority of the SMEs in our dataset appear to rely on a combination of high contract complexity and high relational trust for various OOI outputs including new and/or enhanced products and processes.

Our results indicate that a combination that maximises and balances both contract complexity and relational trust mechanisms may represent the most effective governance type for the control and coordination of SMEs' OOI relationships. Additionally, this result informs us that when pursuing innovation through offshore outsourcing, SMEs behave consistently with large firms. In other words, SMEs implement dual-mode governance of contract 
Governance of offshore outsourcing innovation by SMEs

complexity and relational trust to curb opportunism through formal ex-ante contractual control (Carson, 2007, Haleem et al., 2018) as well as enable better tacit knowledge disclosure and mutual learning through relational trust (Kulangara et al., 2016, Bordonaba-Juste and CambraFierro, 2009). Our two complementarity tests provide support to this conclusion by revealing that SME managers may complement the use of contract complexity with the use of relational trust to benefit from the synergetic advantages of both governance mechanisms in driving higher OOI outcomes, while simultaneously promoting long term continuation of the relationship and safeguarding specific investments from premature and costly termination (Poppo and Zenger, 2002).

Drawing upon these results we forward a 4F governance mechanism involving four different types as a) fit for high contract complexity/high relational trust, b) firm for high contract complexity/low relational trust, c) flexible for low contract complexity/high relational trust, and d) fragile for low contract complexity/low relational trust (Figure 3). Figure 3 displays the $4 \mathrm{~F}$ governance matrix in four quadrants each with a different capacity of outsourcing efficiency (e.g. reducing costs, controlling opportunism, and achieving innovation targets) and innovation adaptability (e.g. navigating technological risks and market uncertainties of innovation outcomes).

The proposed 4F governance matrix structure encapsulates the tenets from both the TCE and relational view. Interfirm relationships that adopt relational governance structures to build trust between partners are generally viewed as substitutes to contractual governance due to the fact that contractual structures are debated to undermine trust and cause opportunistic behaviour (Poppo and Zenger, 2002). The proponents of TCE add that although relational structures could lead to better performance than contractual governance (Wacker et al., 2016), a single governance mechanism, on its own, is not sufficient to regulate structural arrangements in interfirm relationships as well as to sustain competitive advantage (Mudambi and Tallman, 
2010, Hernández-Espallardo et al., 2010). Accordingly, studies that underpin these theoretical anchors emphasize the need for firms to implement a combination of governance structures a combination of contractual and relational governance in our case - as they could complement each other (Cao and Lumineau, 2015, Wacker et al., 2016) and subsequently enhance relationship performance (Cao and Lumineau, 2015). Along these lines of thought, our 4F model that proposes various combinations of relational and contractual structures, evidently encompasses the tenets of both TCE and relational view theories. The 4F model further complements the views that suggest the need for outsourcing firms, in particular, to adopt a combination of governance structures (Mudambi and Tallman, 2010, Cao and Lumineau, 2015) - a form of hybrid governance as stated in TCE debates (Williamson, 1991) - to prevent such firms from the hazards (distrust and opportunism) of relying on a single governance mechanism (Hernández-Espallardo et al., 2010).

\section{[Insert Figure 3 about here]}

The fit governance type represents the most efficient and adaptive alternative. Through high levels of contract complexity, the fit governance keeps tight control over transactions cost by detailing each party's roles and responsibilities, specifying procedures to ensure compliance, and determining expected outcomes (Poppo and Zenger, 2002); moreover, contract complexity controls for suppliers' opportunism through detailed legal consequences in case of protected IP violations (Kloyer and Scholderer, 2012). Similarly, through maximising relational trust, the fit governance emphasises parties' willingness to rely on trust to adapt with uncertainties and perceived risks of future outsourcing innovation outcomes (Dyer and Singh, 1998). Accordingly, the majority of SMEs in our dataset have chosen the fit type as their effective governance to deal with OOI tasks and complexities.

In contrast, the fragile governance type is characterised by a lack of adequate contract complexity and relational trust. Consequently, the fragile governance has weak capacities of 
interfirm formal and informal systems to measure parties' contractual compliance, performance efficiency and levels of commitment in the relationships. Also, fragile governance suffers from the absence of necessary adaptive responses to navigate the uncertainties and risks of innovation. Our results support this conclusion since only 9 SMEs (4.5\% of the 200 SMEs in our sample) reported achieving high OOI performance though adopting fragile governance of low contract complexity and low relational trust. The other 69 SMEs $(34.5 \%$ of the 200 SMEs in our sample) in the fragile group reported low OOI performance. The question this result poses though is why an SME firm would select a fragile governance structure in managing an OOI relationship? A possible answer could be that in their haste to exploit significant opportunities offered by fast technologies and emerging markets, SMEs might try to follow the steps of large firms in OOI without having sufficient organisational resources to vet selected suppliers or control them. Consequently, they fall into the trap of blind trust. This rationale might explain the disappointing results and the higher failure rate of SMEs in many developed countries and across various industries (Terziovski, 2010).

The other two types of governance, the firm and the flexible, although exhibit the high capacity of adaptability or high efficiency respectively; they both are vulnerable to falling in the trap of the excessive reliance on contract complexity or relational trust. Often, tight contracts in the firm governance type engender rigidity between outsourcing partners, which in turn restricts the generation of new ideas and obstructs the open flow of information (Hoecht and Trott, 2006). In the context of SMEs, overly cooked OOI contracts are prone to failure more than success in delivering high OOI performance, given the scarcity of time that SMEs owners/managers can devote to interpret, maintain and adjust complex contracts (Pittino and Mazzurana, 2013). Moreover, the cost of legally enforcing complex OOI contracts likely exceeds the resources of SMEs especially if the legal systems in the selected offshore country was weaker than the SME domestic legal system. 
Likewise, too much trust in the flexible governance type can harm the OOI relationship. On the one hand, despite their mastery of relational governance, SMEs must be aware of their vulnerability while pursuing OOI in terms of the potential negative consequences of the offshore supplier misappropriation of their tacit knowledge (O'Dwyer and O'Flynn, 2005). Moreover, conducting OOI in offshore countries exposes the outsourcing SMEs to foreign and possibly new contextual complexity (Pawar et al., 2020); and venturing-in contractually unguarded might not be a right choice of governance. On the other hand, too much trust can block good criticism, build up group thinking and consequently lead to missing innovation and efficiency targets (Bidault and Castello, 2010). Finally, both the firm and the flexible governance types fail to benefit from the synergetic complementarity value of combining contract complexity with relational trust. For example, complex contracts enhance trust building through legal and economic commitments, while relational trust allows contractual disputes resolution in the face of unforeseen contingencies (Poppo and Zenger, 2002).

The proposed $4 \mathrm{~F}$ governance contributes to extant literature focusing on the use of various governance mechanisms in buyer-supplier relationships in general (Lee and Cavusgil, 2006, Hernández-Espallardo et al., 2010, Wiengarten et al., 2013, Kembro et al., 2014, Melander et al., 2014), and SMEs in particular (Ciliberti et al., 2009, Devos et al., 2012, Prajogo et al., 2020). For instance, the use of trust-based governance mechanisms (Lee and Cavusgil, 2006) or contracts with complementary practices are said to positively impact performance outcomes in interfirm relationships (Lee and Cavusgil, 2006, Wiengarten et al., 2013). Others indicate that combining both trust and contract governance would provide better performance benefits for the relationship (Liu et al., 2009, Melander et al., 2014). Although previous studies have discussed the interplay of these governance forms in various contexts (Cao and Lumineau, 2015), there is a lack of knowledge that can explain the significance of various combinations of trust and contract-based governance mechanisms for SMEs that are involved in offshore 
relationships. Studies have recognised the importance of this line of enquiry and have subsequently called for further investigations on potential combinations of governance forms for SMEs in general (Toxopeus et al., 2020, Mirkovski et al., 2016), and outsourcing offshore context in particular (Wiengarten et al., 2013, Haleem et al., 2018). This importance is further reflected in research that argues neither relational nor contract governance alone to be sufficient for outsourcing SMEs to enhance performance outcomes (Devos et al., 2012); they can be insufficient to balance efficiencies and uncertainties (Prajogo et al., 2020, Melander et al., 2014). Our 4F model makes significant contributions in this direction in that is adds fit governance form (a combination of strong contract as well as trust-based governance) as an effective form of governance for offshoring SMEs to balance efficiencies and complexities in their OOI relationships.

\section{The effects of formal knowledge routines and supplier joint actions}

Our results show that engaging formal knowledge routines and supplier joint actions as part of a portfolio of explicit partnering and cooperative norms can help in solving for the opposing tension between contract complexity and innovation performance in outsourcing innovation relationships (Aubert et al., 2015). First, by addressing IP access, use and protection, formal knowledge routines can add value to contract complexity not only by explicitly addressing the SME's concerns of IP potential leakage, but also by expanding knowledge protection to include a two-way knowledge accessing, sharing and application at the same time (Kloyer and Scholderer, 2012). This finding supports calls for investing in interfirm formal knowledge routines and supplier development (Lai et al., 2009, Roy and Sivakumar, 2011, Sumo et al., 2016, Prajogo et al., 2020). Second, it appears that by implementing partnering routines such as supplier joint actions, SMEs claim a collaborative attitude and become more efficient in controlling and coordinating the offshore supplier behaviour. Consequently, the OOI contracts become more efficient in driving increased suppliers' compliance towards achieving higher innovation outcomes. 
Contrary to our prediction, our results do not support the positive significant moderating effects of formal knowledge routines or supplier joint actions on the impact of relational trust on OOI performance. Instead, negative insignificant moderating effects are found. We hypothesised based on previous studies that formal knowledge routine and supplier joint actions highlight to OOI partners the positive gains of collaborative innovation, thus, stimulating the effect of relational trust in driving stronger OOI performance (Levin and Cross, 2004, van den Ende et al., 2015). We also conjectured that relational trust in OOI relationships becomes more meaningful as a result of the dyad's partnership posturing signalled through formal knowledge routines and supplier joint actions (Koufteros et al., 2012).

The competing effects of formal knowledge routines might explain this counterintuitive finding. First, it could be that the regulatory nature of formal knowledge routines limits mutual disclosure and consequently, undermines the role of relational trust in generating innovative OOI outcomes (Ritala et al., 2015). Likewise, despite the supplier's potential gains, they might not be high enough to motivate the supplier trusting behaviour. For example, Gilliland and Kim (2013) argued that in buyer-supplier relationships, the supplier's perception of the incentives gained through joint actions is important. Therefore, incentives must be closely aligned with supplier expectations so as to ensure the supplier's commitment towards improving OOI (Gilliland and Kim, 2013, Khraishi et al., 2020).

Second, we purposefully measured the non-calculative component of trust (benevolence) to separate its contributions in OOI outcomes from the calculative trust (e.g. a trustee's competence and integrity) (Saparito et al., 2004). However, the calculative trust which concerns with the SME buyer's confidence expectations of the offshore supplier's abilities and integrity to behave per acceptable principles might have responded differently to the implementation of formal knowledge routines and supplier joint actions (Mayer et al., 1995, Levin and Cross, 2004). Third, despite parties' high commitment to a win-win mentality via 
formal knowledge routines and supplier joint actions, the two factors might not be sufficient for strengthening the relationship between relational trust and OOI performance. Other factors such as extensive exchange history in OOI might also be required to enable the moderating influence of formal knowledge routines and supplier joint actions on relational trust (Gulati and Sytch, 2008, Noordhoff et al., 2011). These enriching results clarify the debates in extant literature about the key factors that could facilitate innovation (Zimmermann et al., 2016) and add to the knowledge that aims to combine trust and contract-based mechanisms and their potential outcomes within the context of SMEs (Mirkovski et al., 2016, Haleem et al., 2018).

Theoretical implications: The study forwards how SMEs could incorporate relational trust and contract complexity mechanisms to enhance innovation performance within OI relationships. We put forth a $4 \mathrm{~F}$ governance framework that builds upon the notion that complex contracts and relational trust are complements in OI relationships (Poppo and Zenger, 2002, Cao and Lumineau, 2015). Particularly, the empirical evidence suggests that majority of SMEs (48\% of SMEs from our dataset) appear to adopt a combination of high levels of relational trust and contract complexity for controlling as well as coordinating SMEs in OI relationships. This finding adds to the stream of research that debates the significance of employing both relational and contractual governance as well as the importance of their complementarity in interfirm buyer-supplier relationships (Liu et al., 2009, Cao and Lumineau, 2015, Hernández-Espallardo et al., 2010). Specifically, the four combinations (fit, flexible, firm, and fragile) of contract and trust/relational governance forms extends existing knowledge on buyer-supplier governance specifically within the context of SME's OI relationships (Poppo and Zenger, 2002, Devos et al., 2012, Johnsen et al., 2019). This is specifically salient given that SMEs are not just small versions of large scale firms (Gusenbauer et al., 2015); previous research that study OI governance in large scale firms might not be directly applicable for SMEs. To this extent, our findings expand current knowledge (Gooroochurn and Hanley, 2007, 
Stanko and Calantone, 2011, Haleem et al., 2018, Johnsen et al., 2019) by arguing that success for SMEs in OI is likely to be dependent on their propensity to implement a fit governance structure that combines both high-levels of relational trust and contract complexity.

As for the moderation effects, the findings shed light on the debates surrounding the benefits that relational norms could offer to both the contract and relational governance adopted by SMEs. Although previous research argue relational norms could benefit the various governance forms (Aubert et al., 2015, Sumo et al., 2016, Lavikka et al., 2015), such complementarities are not well-established within SMEs' OOI context. Importantly, given that SMEs are smaller in size and struggle with resource limitations, it is important for them to develop trust and commitment with their supplier partners particularly in offshoring settings (Bidault and Castello, 2010, Haleem et al., 2018) to develop and sustain their relationships. Earlier studies seek strengthening of the governance forms in buyer-supplier relationships in order to enhance performance outcomes (Mirkovski et al., 2016). To this extent, our study puts forth that the complementarity of 'knowledge routines' and 'joint actions' for contract and trust-based governance mechanisms will affect SMEs' OI performance differently.

Managerial implications: The 4F governance model offers SME managers with useful tools to guide their firm's limited resources towards optimising fit governance of high relational trust and complex contracts. Therefore, a SME's manager can utilize the 4F model to determine the type of governance structure that needs to be implemented in the OI relationship with a partner based on the transactional needs as well as the relational environment at any given point of time. The SME can then make gradual moves from being in a 'fragile' governance zone, to firm, and flexible, to the fit governance structure as the firm shifts its focus from low transaction costs, strict control, trust-based relationship towards attaining innovations. Furthermore, findings inform managers that, in practice, SMEs exhibit propensity toward adopting fit governance of detailed contractual safeguards (contract complexity) and extensive 
Governance of offshore outsourcing innovation by SMEs

socialisation (relational trust) in managing their OOI relationships. Additionally, although the fit governance type represents an ideal case and hence a difficult configuration to achieve and sustain, it is worthwhile for SMEs to invest in the relationship with the offshore supplier to emulate fit governance. Furthermore, governance mechanisms can become more conducive to OOI through partnering norms such as formal knowledge routines and supplier joint actions since they can substantially shape the exchange outcomes.

\section{Conclusion}

The present study extends interfirm research on contractual and relational governance of interfirm OOI relationships. Our research supports that despite SMEs' small size characteristics, they follow large firms' recipe of dual-mode governance of contract complexity and relational trust in managing their OOI relationships. Moreover, SME success in offshore outsourcing relationships depends on the implementation of a fit governance structure (Carson, 2007, Gooroochurn and Hanley, 2007, Hoecht and Trott, 2006, Stanko and Calantone, 2011). Also, by focusing on OOI in a buyer-supplier context, we shed light on the high complexity surrounding OOI control and coordination in non-equity relationships.

As with any research, our study also has several limitations. First, we sampled SMEs from the manufacturing population in the UK, Germany, France, and Italy. Therefore, our results have limited generalisability. Future research can include samples from a broader set of a population in different countries and industries. Second, we collected data from European SME buyer's perspective. It would be interesting to explore in future research the offshore suppliers' perspectives on effective governance structures in OOI relationships. Third, we studied the moderation effects of formal knowledge routines and supplier joint actions; future research can address other factors such as goal compatibility, organisational similarity (Gulati and Sytch, 2008) or contracts types. Future research could also examine the impact of all constructs in our model on firm, operational and financial performance. Furthermore, it would 
also be interesting to study whether SMEs should rather abstain from utilizing OOI given the complexities revolving around the management of such strategies. Despite these limitations, our study provides valuable insights into how SMEs can effectively deploy contract complexity and relational trust to foster OOI success.

\section{References}

ABBEY, J. D. \& MELOY, M. G. 2017. Attention by design: Using attention checks to detect inattentive respondents and improve data quality. Journal of Operations Management, 53-56, 63-70.

ARCHER, N., WANG, S. \& KANG, C. 2008. Barriers to the adoption of online supply chain solutions in small and medium enterprises. Supply chain management: An international journal, 13, $73-$ 82.

AUBERT, B. A., KISHORE, R. \& IRIYAMA, A. 2015. Exploring and managing the "innovation through outsourcing" paradox. The journal of strategic information systems, 24, 255-269.

BIDAULT, F. \& CASTELLO, A. 2010. Why too much trust is death to innovation. MIT Sloan management review, 51, 33.

BORDONABA-JUSTE, V. \& CAMBRA-FIERRO, J. J. 2009. Managing supply chain in the context of SMEs: a collaborative and customized partnership with the suppliers as the key for success. Supply chain management, 14, 393-402.

BRAZHKIN, V. 2020. "I have just returned from the moon:" online survey fraud. Supply chain management, 25, 489-503.

CAO, Z. \& LUMINEAU, F. 2015. Revisiting the interplay between contractual and relational governance: A qualitative and meta-analytic investigation. Journal of Operations Management, 33-34, 15.

CARSON, S. J. 2007. When to Give Up Control of Outsourced New Product Development. Journal of marketing, 71, 49-66.

CASSIMAN, B. \& VEUGELERS, R. 2006. In Search of Complementarity in Innovation Strategy: Internal R\&D and External Knowledge Acquisition. Management science, 52, 68-82.

CHEN, D. Q., PRESTON, D. S. \& XIA, W. 2013. Enhancing hospital supply chain performance: A relational view and empirical test. Journal of operations management, 31, 391-408.

CHOU, S. W., TECHATASSANASOONTORN, A. A. \& HUNG, I. H. 2015. Understanding commitment in business process outsourcing relationships. Information \& management, 52, 30-43.

CILIBERTI, F., DE GROOT, G., DE HAAN, J. \& PONTRANDOLFO, P. 2009. Codes to coordinate supply chains: SMEs' experiences with SA8000. Supply chain management, 14, 117-127.

DE MARCO, C. E., MARTELLI, I. \& DI MININ, A. 2020. European SMEs' engagement in open innovation When the important thing is to win and not just to participate, what should innovation policy do? Technological forecasting \& social change, 152, 119843.

DEVOS, J., VAN LANDEGHEM, H. \& DESCHOOLMEESTER, D. 2012. Rethinking IT governance for SMEs. Industrial management + data systems, 112, 206-223.

DI GREGORIO, D., MUSTEEN, M. \& THOMAS, D. E. 2009. Offshore Outsourcing as a Source of International Competitiveness for SMEs. Journal of international business studies, 40, 969988.

DYER, J. 1996. SPECIALIZED SUPPLIER NETWORKS AS A SOURCE OF COMPETITIVE ADVANTAGE: EVIDENCE FROM THE AUTO INDUSTRY. Strategic Management Journal, 17, 271-291.

DYER, J. \& SINGH, H. 1998. The relational view: cooperative strategy and sources of interorganizational competitive advantage. Academy of Management review, 23, 660-679. 
DYER, J. H., SINGH, H. \& HESTERLY, W. S. 2018. The relational view revisited: A dynamic perspective on value creation and value capture. Strategic management journal, 39, 3140-3162.

EASME 2018. Innovation Kitchen - Horizon 2020 SME instrument impact report. Luxembourg.

EUROPEAN-COMMISSION 2016. Annual Report on European SMEs 2015 / 2016: SME recovery continues. Luxembourg.

EUROPEAN-COMMISSION 2017. Annual Report on European SMEs 2016/2017 Focus on Selfemployment. Luxembourg.

EUROPEAN-COMMISSION 2019. Annual Report on European SMEs 2018/2019 Research and Development and Innovation by SMEs. Luxembourg.

EUROSTAT 2016. Eurostart yearbook Luxembourg (LU): European Union.

EUROSTAT 2017. Eurostat yearbook [Online]. Luxembourg (LU): European Union.

FELIN, T. \& ZENGER, T. R. 2014. Closed or open innovation? Problem solving and the governance choice. Research policy, 43, 914-925.

FERGUSON, R. J., PAULIN, M. \& BERGERON, J. 2005. Contractual Governance, Relational Governance, and the Performance of Interfirm Service Exchanges: The Influence of Boundary-Spanner Closeness. Journal of the Academy of Marketing Science, 33, 217-234.

FORNELL, C. \& LARCKER, D. 1981. Evaluating Structural Equation Models with Unobservable Variables and Measurement Error. Journal of Marketing Research, 18, 39.

GEISHECKER, I. \& GÖRG, H. 2013. Services offshoring and wages: Evidence from micro data. Oxford economic papers, 65, 124-146.

GILLILAND, D. I. \& KIM, S. K. 2013. When do incentives work in channels of distribution? Journal of the Academy of Marketing Science, 42, 361-379.

GLAS, A. H. \& EßIG, M. 2018. Factors that influence the success of small and medium-sized suppliers in public procurement: evidence from a centralized agency in Germany. Supply chain management: An international journal, 23, 65-78.

GLOBERMAN, S. \& NIELSEN, B. B. 2007. Equity versus non-equity international strategic alliances involving Danish firms: An empirical investigation of the relative importance of partner and host country determinants. Journal of international management, 13, 449-471.

GOOROOCHURN, N. \& HANLEY, A. 2007. A tale of two literatures: Transaction costs and property rights in innovation outsourcing. Research policy, 36, 1483-1495.

GULATI, R. \& SYTCH, M. 2008. Does familiarity breed trust? Revisiting the antecedents of trust. Managerial and decision economics, 29, 165-190.

GUSENBAUER, M., MASSINI, S. \& FINK, M. 2015. Innovation Offshoring by Small and Medium-Sized Enterprises - Establishing the Research Gap. Cham: Springer International Publishing.

HALEEM, F., FAROOQ, S., WAEHRENS, B. V. \& BOER, H. 2018. Offshoring experience and performance: the role of realized drivers and risk management. Supply Chain Management: An International Journal, 23, 531-544.

HANDLEY, S. M. \& BENTON, W. C. 2013. The influence of task- and location-specific complexity on the control and coordination costs in global outsourcing relationships. Journal of operations management, 31, 109-128.

HELEN, W., FREDO, S., ELMER, B. \& CHRISTINE, H. 2013. Collaborative Procurement: A Relational View of Buyer-Buyer Relationships. Public administration review, 73, 588-598.

HERNÁNDEZ-ESPALLARDO, M., RODRÍGUEZ-OREJUELA, A. \& SÁNCHEZ-PÉREZ, M. 2010. Interorganizational governance, learning and performance in supply chains. Supply chain management, 15, 101-114.

HOECHT, A. \& TROTT, P. 2006. Innovation risks of strategic outsourcing. Technovation, 26, 672-681.

HUQ, F. A. \& STEVENSON, M. 2020. Implementing Socially Sustainable Practices in Challenging Institutional Contexts: Building Theory from Seven Developing Country Supplier Cases. Journal of business ethics, 161, 415-442. 
HUQ, F. A., STEVENSON, M. \& ZORZINI, M. 2014. Social sustainability in developing country suppliers: An exploratory study in the ready made garments industry of Bangladesh. International journal of operations \& production management, 34, 610-638.

JEAN, R.-J. B., KIM, D. \& SINKOVICS, R. R. 2012. Drivers and Performance Outcomes of Supplier Innovation Generation in Customer-Supplier Relationships: The Role of Power-Dependence. Decision sciences, 43, 1003-1038.

JOHNSEN, T. E., MIKKELSEN, O. S. \& WONG, C. Y. 2019. Strategies for complex supply networks: findings from the offshore wind power industry. Supply chain management, 24, 872-886.

JOSHI, A. W. \& STUMP, R. L. 1999. The contingent effect of specific asset investments on joint action in manufacturer-supplier relationships: An empirical test of the moderating role of reciprocal asset investments, uncertainty, and trust. Journal of the Academy of Marketing Science, 27, 291-305.

KEMBRO, J., SELVIARIDIS, K. \& NÄSLUND, D. 2014. Theoretical perspectives on information sharing in supply chains: a systematic literature review and conceptual framework. Supply chain management, 19, 609-625.

KHRAISHI, A., HUQ, F. \& PAULRAJ, A. 2020. Offshoring innovation: An empirical investigation of dyadic complementarity within SMEs. Journal of business research, 118, 86-97.

KIM, Y., CHOI, T. Y. \& SKILTON, P. F. 2015. Buyer-supplier embeddedness and patterns of innovation. International Journal of Operations \& Production Management, 35, 318-345.

KLOYER, M. \& SCHOLDERER, J. 2012. Effective incomplete contracts and milestones in market-distant R\&D collaboration. Research policy, 41, 346-357.

KOUFTEROS, X., VICKERY, S. K. \& DRÖGE, C. 2012. The Effects of Strategic Supplier Selection on Buyer Competitive Performance in Matched Domains: Does Supplier Integration Mediate the Relationships? The journal of supply chain management, 48, 93-115.

KÜHNE, B., GELLYNCK, X. \& WEAVER, R. D. 2013. The influence of relationship quality on the innovation capacity in traditional food chains. Supply chain management: An international journal, 18, 52-65.

KULANGARA, N. P., JACKSON, S. A. \& PRATER, E. 2016. Examining the impact of socialization and information sharing and the mediating effect of trust on innovation capability. International journal of operations \& production management, 36, 1601-1624.

KULL, T. J., KOTLAR, J. \& SPRING, M. 2018. Small and Medium Enterprise Research in Supply Chain Management: The Case for Single-Respondent Research Designs. The journal of supply chain management, 54, 23-34.

KWON, I. W. G. \& SUH, T. 2004. Factors Affecting the Level of Trust and Commitment in Supply Chain Relationships. Journal of Supply Chain Management, 40, 4-14.

LAI, E., L. C., RIEZMAN, R. \& WANG, P. 2009. Outsourcing of Innovation. Economic theory, 38, 485515.

LAVIKKA, R. H., SMEDS, R. \& JAATINEN, M. 2015. Coordinating collaboration in contractually different complex construction projects. Supply chain management, 20, 205-217.

LEE, Y. \& CAVUSGIL, S. T. 2006. Enhancing alliance performance: The effects of contractual-based versus relational-based governance. Journal of Business Research, 59, 896-905.

LEVIN, D. Z. \& CROSS, R. 2004. The Strength of Weak Ties You Can Trust: The Mediating Role of Trust in Effective Knowledge Transfer. Management science, 50, 1477-1490.

LEWIN, A. Y., MASSINI, S. \& PEETERS, C. 2009. Why are companies offshoring innovation? The emerging global race for talent. Journal of international business studies, 40, 901-925.

LINCOLN, Y. S. \& GUBA, E. G. 1985. Naturalistic enquiry, Newbury Park, Sage.

LIU, C.-L., GHAURI, P. N. \& SINKOVICS, R. R. 2010. Understanding the impact of relational capital and organizational learning on alliance outcomes. Journal of world business : JWB, 45, 237-249.

LIU, Y., LUO, Y. \& LIU, T. 2009. Governing buyer-supplier relationships through transactional and relational mechanisms: Evidence from China. Journal of Operations Management, 27, 294309. 
MADHOK, A. 2002. Reassessing the Fundamentals and beyond: Ronald Coase, the Transaction Cost and Resource-Based Theories of the Firm and the Institutional Structure of Production. Strategic management journal, 23, 535-550.

MARSHALL, D., MCIVOR, R. \& LAMMING, R. 2007. Influences and outcomes of outsourcing: Insights from the telecommunications industry. Journal of purchasing and supply management, 13, 245-260.

MAYER, R. C., DAVIS, J. H. \& SCHOORMAN, F. D. 1995. An Integrative Model of Organizational Trust. The Academy of Management review, 20, 709-734.

MCIVOR, R. 2005. The outsourcing process : strategies for evaluation and management, Cambridge, Cambridge University Press.

MCIVOR, R. 2009. How the transaction cost and resource-based theories of the firm inform outsourcing evaluation. Journal of operations management, 27, 45-63.

MELANDER, L., ROSELL, D. \& LAKEMOND, N. 2014. In pursuit of control: involving suppliers of critical technologies in new product development. Supply chain management, 19, 722-732.

MIRKOVSKI, K., LOWRY, P. B. \& FENG, B. 2016. Factors that influence interorganizational use of information and communications technology in relationship-based supply chains: evidence from the Macedonian and American wine industries. Supply Chain Management: An International Journal, 21, 334-351.

MOOI, E. A. \& GHOSH, M. 2010. Contract Specificity and Its Performance Implications. Journal of marketing, 74, 105-120.

MUDAMBI, S. M. \& TALLMAN, S. 2010. Make, Buy or Ally? Theoretical Perspectives on Knowledge Process Outsourcing through Alliances. Journal of management studies, 47, 1434-1456.

MUKHERJEE, D., LAHIRI, S., ASH, S. R. \& GAUR, A. S. 2019. Search motives, local embeddedness, and knowledge outcomes in offshoring. Journal of business research, 103, 365-375.

NOORDHOFF, C. S., KYRIAKOPOULOS, K., MOORMAN, C., PAUWELS, P. \& DELLAERT, B. 2011. The bright-side and dark-side effects of embedded ties in business-to-business innovation. Journal of marketing, 75, 34-52.

NOORDHOFF, C. S., KYRIAKOPOULOS, K., MOORMAN, C., PAUWELS, P. \& DELLAERT, B. G. C. 2018. The Bright Side and Dark Side of Embedded Ties in Business-to-Business Innovation. Journal of marketing, 75, 34-52.

O'DWYER, M. \& O'FLYNN, E. 2005. MNC-SME strategic alliances - A model framing knowledge value as the primary predictor of governance modal choice. Journal of international management, 11, 397-416.

OECD 2011. Technology Intensity Definition.

PALMIÉ, M., ZESCHKY, M., WINTERHALTER, S., SAUTER, P. W., HAEFNER, N. \& GASSMANN, O. 2015. Coordination mechanisms for international innovation in SMEs: effects on time-to-market and R\&D task complexity as a moderator. Small business economics, 46, 273-294.

PAULRAJ, A., LADO, A. A. \& CHEN, I. J. 2008. Inter-organizational communication as a relational competency: Antecedents and performance outcomes in collaborative buyer-supplier relationships. Journal of Operations Management, 26, 45-64.

PAWAR, K. S., HUQ, F. A., KHRAISHI, A. \& SHAH, J. 2020. Contextualisation of the complexity in the selection of developing country outsourcees by developed country outsourcers. International journal of production research, 57, 4310-4332.

PETERAF, M. A. 1993. The cornerstones of competitive advantage: A resource-based view. Strategic management journal, 14, 179-191.

PITTINO, D. \& MAZZURANA, P. A. M. 2013. Alliance Governance and Performance in SMEs: Matching Relational and Contractual Governance with Alliance Goals. Entrepreneurship research journal, 3, 62-83.

POPPO, L. \& ZENGER, T. 2002. Do formal contracts and relational governance function as substitutes or complements? Strategic management journal, 23, 707-725. 
PRAJOGO, D., CHOWDHURY, M., NAIR, A. \& CHENG, T. C. E. 2020. Mitigating the performance implications of buyer's dependence on supplier: the role of absorptive capacity and longterm relationship. Supply chain management, 25, 693-707.

QUINN, J. B. 2000. Outsourcing Innovation: The New Engine of Growth. MIT Sloan management review, 41, 13.

RIBBINK, D. \& GRIMM, C. M. 2014. The impact of cultural differences on buyer-supplier negotiations: An experimental study. Journal of operations management, 32, 114-126.

RINDFLEISCH, A. \& MOORMAN, C. 2001. The Acquisition and Utilization of Information in New Product Alliances: A Strength-of-Ties Perspective. Journal of marketing, 65, 1-18.

RING, P. S. \& VAN DE VEN, A. H. 1994. Developmental Processes of Cooperative Interorganizational Relationships. The Academy of Management review, 19, 90-118.

RITALA, P., OLANDER, H., MICHAILOVA, S. \& HUSTED, K. 2015. Knowledge sharing, knowledge leaking and relative innovation performance: An empirical study. Technovation, 35, 22-31.

RODRÍGUEZ, A. \& NIETO, M. J. 2016. Does R\&D offshoring lead to SME growth? Different governance modes and the mediating role of innovation. Strategic management journal, 37, 1734-1753.

ROPER, S., DU, J. \& LOVE, J. H. 2008. Modelling the innovation value chain. Research policy, 37, 961977.

ROY, S. \& SIVAKUMAR, K. 2011. Managing Intellectual Property in Global Outsourcing for Innovation Generation: Managing Intellectual Property in Global Outsourcing. The Journal of product innovation management, 28, 48-62.

SANCHEZ, J., I. \& BROCK, P. 1996. Outcomes of Perceived Discrimination among Hispanic Employees: Is Diversity Management a Luxury or a Necessity? Academy of Management journal, 39, 704719.

SAPARITO, P. A., CHEN, C. C. \& SAPIENZA, H. J. 2004. The Role of Relational Trust in Bank-Small Firm Relationships. Academy of Management journal, 47, 400-410.

SCHMOLTZI, C. \& WALLENBURG, C. M. 2012. Operational Governance in Horizontal Cooperations of Logistics Service Providers: Performance Effects and the Moderating Role of Cooperation Complexity. Journal of Supply Chain Management, 48, 53-74.

SEEPANA, C., HUQ, F. A. \& PAULRAJ, A. 2021. Performance effects of entrepreneurial orientation, strategic intent and absorptive capacity within coopetitive relationships. International journal of operations \& production management, 41, 227-250.

SEEPANA, C., PAULRAJ, A. \& HUQ, F. A. 2020. The architecture of coopetition: Strategic intent, ambidextrous managers, and knowledge sharing. Industrial marketing management, 91, 100-113.

SHEPHERD, D. A. \& DETIENNE, D. R. 2005. Prior Knowledge, Potential Financial Reward, and Opportunity Identification. Entrepreneurship theory and practice, 29, 91-112.

SILVERMAN, B. S. 1999. Technological Resources and the Direction of Corporate Diversification: Toward an Integration of the Resource-Based View and Transaction Cost Economics. Management science, 45, 1109-1124.

STANKO, M. A. \& CALANTONE, R. J. 2011. Controversy in innovation outsourcing research: review, synthesis and future directions. $R$ \& D management, 41, 8-20.

STATSENKO, L. \& CORRAL DE ZUBIELQUI, G. 2020. Customer collaboration, service firms' diversification and innovation performance. Industrial Marketing Management, 85, 180-196.

STRATMAN, J. K. 2008. Facilitating offshoring with enterprise technologies: Reducing operational friction in the governance and production of services. Journal of operations management, 26, 275-287.

SUMO, R., VAN DER VALK, W., VAN WEELE, A. \& BODE, C. 2016. Fostering incremental and radical innovation through performance-based contracting in buyer-supplier relationships. International Journal of Operations \& Production Management, 36, 1482-1503. 
SWIERCZEK, A. 2019. The effects of brokered network governance on relational embeddedness in the triadic supply chains: is there a room for the "Coleman rent"? Supply chain management, 25, 301-323.

TERZIOVSKI, M. 2010. Innovation practice and its performance implications in small and medium enterprises (SMEs) in the manufacturing sector: a resource-based view. Strategic management journal, 31, 892-902.

TOXOPEUS, H., KOTSILA, P., CONDE, M., KATONA, A., VAN DER JAGT, A. P. N. \& POLZIN, F. 2020. How 'just' is hybrid governance of urban nature-based solutions? Cities, 105, 102839.

VAN DE VRANDE, V., DE JONG, J. P. J., VANHAVERBEKE, W. \& DE ROCHEMONT, M. 2009. Open innovation in SMEs: Trends, motives and management challenges. Technovation, 29, 423437.

VAN DEN ENDE, J., FREDERIKSEN, L. \& PRENCIPE, A. 2015. The Front End of Innovation: Organizing Search for Ideas. The Journal of product innovation management, 32, 482-487.

VAN DER VALK, W., SUMO, R., DUL, J. \& SCHROEDER, R. G. 2016. When are contracts and trust necessary for innovation in buyer-supplier relationships? A Necessary Condition Analysis. Journal of purchasing and supply management, 22, 266-277.

VIVEK, S. D., BANWET, D. K. \& SHANKAR, R. 2008. Analysis of interactions among core, transaction and relationship-specific investments: The case of offshoring. Journal of operations management, 26, 180-197.

VIVEK, S. D., RICHEY, R. G. \& DALELA, V. 2009. A longitudinal examination of partnership governance in offshoring: A moving target. Journal of world business : JWB, 44, 16-30.

WACKER, J. G., CHENLUNG, Y. \& CHWEN, S. 2016. A transaction cost economics model for estimating performance effectiveness of relational and contractual governance: Theory and statistical results. International journal of operations \& production management, 36, 1551-1575.

WIENGARTEN, F., PAGELL, M. \& FYNES, B. 2013. The importance of contextual factors in the success of outsourcing contracts in the supply chain environment: the role of risk and complementary practices. Supply chain management, 18, 630-643.

WILLIAMSON, O. E. 1991. Comparative Economic Organization: The Analysis of Discrete Structural Alternatives. Administrative Science Quarterly, 36, 219-44.

YOUNGDAHL, W., RAMASWAMY, K. \& VERMA, R. 2008. Exploring new research frontiers in offshoring knowledge and service processes. Journal of operations management, 26, 135140.

ZAHEER, A., MCEVILY, B. \& PERRONE, V. 1998. Does Trust Matter? Exploring the Effects of Interorganizational and Interpersonal Trust on Performance. Organization science (Providence, R.I.), 9, 141-159.

ZIMMERMANN, R., D.F. FERREIRA, L. M. \& CARRIZO MOREIRA, A. 2016. The influence of supply chain on the innovation process: a systematic literature review. Supply chain management, 21, 289-304. 


\section{Appendix}

Construct (Cronbach's alpha, composite reliability (CR), average variance extracted (AVE)

Loadings

Contract complexity $(\alpha=0.78 ; C R=0.79 ;$ AVE $=0.56)$

a) Our formal contract with the offshore supplier is long and extensive.

0.86

b) Our formal contract with the offshore supplier is highly customized and required

considerable legal work.

c) Our formal contract includes rules and regulations to govern our relationship.

d) Our formal contract with the offshore supplier is adapted to our firm's specific needs. *

Relational trust $(\alpha=0.73 ; \mathrm{CR}=0.77 ; \mathrm{AVE}=0.53)$

a) The offshore supplier usually keeps the promises that it makes to our firm.

b) We can count on the offshore supplier to be sincere.

c) When making important decisions, the offshore supplier is concerned about our welfare.

d) The offshore supplier has always been even-handed in its negotiations with our firm.*

\section{Formal knowledge routines $(\alpha=0.73 ; \mathrm{CR}=0.74 ; \mathrm{AVE}=0.50$ )}

a) We rely extensively on contractual rules in controlling day-to-day knowledge sharing with the offshore supplier.

b) We follow written procedures in most aspects of knowledge sharing with the offshore supplier. *

c) Our relationship with the offshore supplier has well-established ground rules about knowledge sharing.

d) We use a common IT (software) to control and coordinate innovation knowledge sharing with the offshore supplier.

\section{Supplier joint actions $(\alpha=0.74 ; C R=0.76 ; A V E=0.52)$}

a) We work jointly with the offshore supplier to reduce its costs

b) We work jointly with the offshore supplier to improve its quality

c) We work jointly with the offshore supplier on training its people

Offshore outsourcing innovation ( $\alpha=0.70 ; C R=0.75 ; A V E=0.51$ )

a) As a result of our relationship with the offshore supplier, we have created new products or enhanced our current products.

b) As a result of our relationship with the offshore supplier, we have created new processes or improved our current processes.

c) As a result of our relationship with the offshore supplier, we have Increased our new product speed to market.

d) As a result of our relationship with the offshore supplier, we have Increased our patent application rate. *

Model fit indices: Normed $X^{2}=1.75(\leq 2.0), p<0.001$, goodness of fit $(\mathrm{GFI})=0.914$, adjusted goodness of fit $(\mathrm{AGFI})=0.870$, comparative fit index $(\mathrm{CFI})=0.949$, Tucker-Lewis index $(\mathrm{TLI})$ $=0.933$, standardised root mean square residuals $(S R M R)=0.053$, and root mean square error of approximation index $($ RMSEA $)=0.061$. Note ${ }^{*}$ Item dropped after CFA 